\title{
Immune Checkpoint Inhibitor Combination Therapy for Renal Cell Carcinomas With Concomitant Inferior Vena Cava Thrombi
}

\author{
KAZUHIKO YOSHIDA ${ }^{1}$, KEISUKE HATA ${ }^{1}$, JUNPEI IIZUKA ${ }^{1}$, TSUNENORI KONDO ${ }^{2}$, \\ HIROKI ISHIHARA ${ }^{2}$, HIDEKI ISHIDA ${ }^{1}$, YOJI NAGASHIMA ${ }^{3}$, KAZUNARI TANABE ${ }^{1}$ and TOSHIO TAKAGI $^{1}$ \\ ${ }^{1}$ Department of Urology, Tokyo Women's Medical University Hospital, Tokyo, Japan; \\ ${ }^{2}$ Department of Urology, Tokyo Women's Medical University Medical Center East, Tokyo, Japan; \\ ${ }^{3}$ Department of Surgical Pathology, Tokyo Women's Medical University Hospital, Tokyo, Japan
}

\begin{abstract}
Background/Aim: The efficacy of immune checkpoint inhibitor (ICI) combinations in treating inferior vena cava (IVC) tumour thrombi has not yet been reported. We aimed to evaluate the clinical efficacy of ICIs for patients with renal cell carcinoma (RCC) and a concomitant IVC tumour thrombus. Patients and Methods: Three men and two women with RCC and an IVC tumour thrombus were administered ICIs in 2020-2021. Three and two patients received nivolumab plus ipilimumab and pembrolizumab plus axitinib therapy, respectively. Results: All ICI-treated patients showed tumour shrinkage. The IVC thrombus level was downstaged in two patients. The mean reduction in maximum primary tumour diameter and IVC thrombus height was 34 and $33 \mathrm{~mm}$, respectively. Conclusion: Presurgical ICI therapy in three patients who underwent radical nephrectomy with thrombectomy resulted in a modified surgical strategy and approach and reduced surgical risk. Thus, ICIs may treat select cases of RCC with an IVC tumour thrombus effectively.
\end{abstract}

Inferior vena cava (IVC) tumour invasion occurs in 4-10\% of patients with renal cell carcinoma (RCC) $(1,2)$. According to the European Association of Urology Guidelines, a strong rating is recommended for the removal of RCC and IVC tumour thrombi in cases of non-metastatic disease without distant metastasis (3). However, complication rates during

This article is freely accessible online.

Correspondence to: Kazuhiko Yoshida, Department of Urology, Tokyo Women's Medical University Hospital, 8-1, Shinjuku-ku, Tokyo, 1868666, Japan. Tel: +81 333538111, e-mail: kzyoshida1@yahoo.co.jp

Key Words: Immune checkpoint inhibitor, inferior vena cava, thrombus, renal cell carcinoma. the operation of IVC tumour thrombi can increase, leading to an upward extension of these thrombi (4). In such cases presurgical treatment, such as with a tyrosine kinase inhibitor (TKI), is expected to shrink the IVC tumour thrombi $(5,6)$. Some TKIs may have a limited reducing effect on the IVC tumour thrombus, contrary to their effect on primary or metastatic tumours (7-10).

Recent guidelines recommend immune checkpoint inhibitor (ICI) combination therapies as a first-line treatment for incurable RCC or metastatic RCC (mRCC) (3). Compared to sunitinib use in mRCC patients, firstline ICI treatment is reportedly associated with a longer overall and progression-free survival and a higher objective response rate. ICIs have, therefore, become standard first-line treatment options for incurable RCC or mRCC $(11,12)$. Hitherto, there has been no report on the efficacy of ICI combinations in the treatment of IVC tumour thrombi. Here, we investigated the efficacy of ICI in patients with RCC and IVC tumour thrombi in terms of primary tumour shrinkage and decrease of the tumour thrombi extent.

\section{Patients and Methods}

Study design and patient data. We retrospectively reviewed the medical records of five RCC patients with concomitant IVC tumour thrombi who received ICIs at Tokyo Women's Medical University Hospital between January 2020 and June 2021 (IRB approval number: 2021-0061).

Data collection. The following clinical data were collected: i) age at which initial treatment was administered, ii) sex, iii) performance status, iv) organs showing metastasis, and v) 2009 tumor, node, metastasis (TNM) classification (13). The risk was characterized using the International Metastatic Renal Cell Carcinoma Database Consortium (IMDC) risk classification system (14). The IVC thrombi staging was performed using Neves and Zincke's classification system (15). 
in vivo $36: 1030-1034(2022)$

Table I. Clinical characteristics of patients with renal cell carcinoma and inferior vena cava tumour thrombi who received combination treatment with immune checkpoint inhibitors.

\begin{tabular}{|c|c|c|c|c|c|c|c|c|c|c|}
\hline No. & $\begin{array}{c}\text { Age } \\
\text { (years) }\end{array}$ & Gender & $\begin{array}{l}\text { IMDC } \\
\text { risk }\end{array}$ & cTMN & ICIs & Metastases & $\begin{array}{c}\text { Treatment } \\
\text { duration } \\
\text { (months) }\end{array}$ & Metastases & $\begin{array}{l}\mathrm{AE} \text { or } \\
\text { irAE }\end{array}$ & Histopathology \\
\hline 1 & 48 & Male & $\begin{array}{c}\text { Poor } \\
(5 \text { factors })\end{array}$ & cT3cN0M1 & $\begin{array}{l}\text { Nivolumab+ } \\
\text { ipilimumab }\end{array}$ & Lung & 20 & $\begin{array}{c}\text { Lung } \\
\text { metastases } \\
\text { disappeared }\end{array}$ & None & Clear-cell RCC \\
\hline 2 & 67 & Female & $\begin{array}{c}\text { Poor } \\
\text { (4 factors) }\end{array}$ & cT3bN0M1 & $\begin{array}{c}\text { Pembrolizumab+ } \\
\text { axitinib }\end{array}$ & Lung & 3 & $\begin{array}{c}\text { Lung } \\
\text { metastases } \\
\text { disappeared }\end{array}$ & None & Clear-cell RCC \\
\hline 3 & 64 & Male & $\begin{array}{l}\text { Intermediate } \\
\text { (1 factor })\end{array}$ & cT3bN0M0 & $\begin{array}{c}\text { Pembrolizumab+ } \\
\text { Axitinib }\end{array}$ & $\begin{array}{l}\text { IVC wall } \\
\text { invasion }\end{array}$ & 1 & None & $\begin{array}{c}\text { Liver } \\
\text { dysfunction }\end{array}$ & Clear-cell RCC \\
\hline 4 & 72 & Male & $\begin{array}{l}\text { Poor } \\
\text { (4 factors) }\end{array}$ & cT3bN2M1 & $\begin{array}{l}\text { Nivolumab+ } \\
\text { ipilimumab }\end{array}$ & Lung, LN & 8 & $\begin{array}{l}\text { All lung and } \\
\text { LN metastases } \\
\text { disappeared }\end{array}$ & Hypopituitarism & Unknown \\
\hline 5 & 72 & Female & $\begin{array}{c}\text { Poor } \\
\text { (5 factors) }\end{array}$ & cT3bN2M1 & $\begin{array}{c}\text { Nivolumab+ } \\
\text { ipilimumab }\end{array}$ & $\begin{array}{l}\text { Brain, } \\
\text { lung, } \\
\text { and LN }\end{array}$ & 18 & $\begin{array}{c}\text { Some lung } \\
\text { metastases } \\
\text { increased }\end{array}$ & $\begin{array}{c}\text { Drug } \\
\text { eruption }\end{array}$ & $\begin{array}{c}\text { Clear-cell } \\
\text { RCC }\end{array}$ \\
\hline
\end{tabular}

IMDC: International Metastatic renal cell carcinoma Database Consortium; cTMN: tumor, node, metastasis; AE: adverse event; ICI: immune checkpoint inhibitor; irAE: immune-related AE; LN: lymph node.

Computed tomography $(C T)$. All images were obtained using 64row detector scanners (Aquilion 64; Canon Medical Systems, Otawara, Japan) or 320-row detector scanners (Aquilion One; Canon Medical Systems).

Magnetic resonance imaging (MRI). MRI imaging was performed using a 1.5-T clinical MRI unit (Gyroscan Intera and Intera; Philips Medical Systems, Best, the Netherlands).

Histology. Upon removal from the patients, the specimens were fixed with $10 \%$ neutralized buffered formalin and embedded in paraffin. The formalin-fixed paraffin-embedded tissues were serially sliced $(5 \mu \mathrm{m})$, followed by H\&E staining.

Treatment outcomes. The objective clinical response in terms of the: i) maximum diameter of the primary tumour $(\mathrm{mm})$, ii) tumour thrombus level, iii) highest tumour thrombus distance (mm) above the renal vein, and iv) largest thrombus diameter ( $\mathrm{mm})$ at its segment, were assessed using CT or MRI. Furthermore, the histopathological effects following ICI therapy in three patients who underwent radical nephrectomy (RN) and IVC thrombectomy were evaluated. Adverse event (AE) grades were based on the Common Terminology Criteria for Adverse Events (CTCAE, version 5.0).

\section{Results}

Five patients, three men and two women, with a mean age of 65 (range $=48-72$ years at the time of treatment initiation) were treated using ICIs for RCC with IVC tumour thrombi. Patient characteristics are summarized in Table I. The thrombus levels were IV in one patient and II in the remaining four patients. Four patients had multiple lung

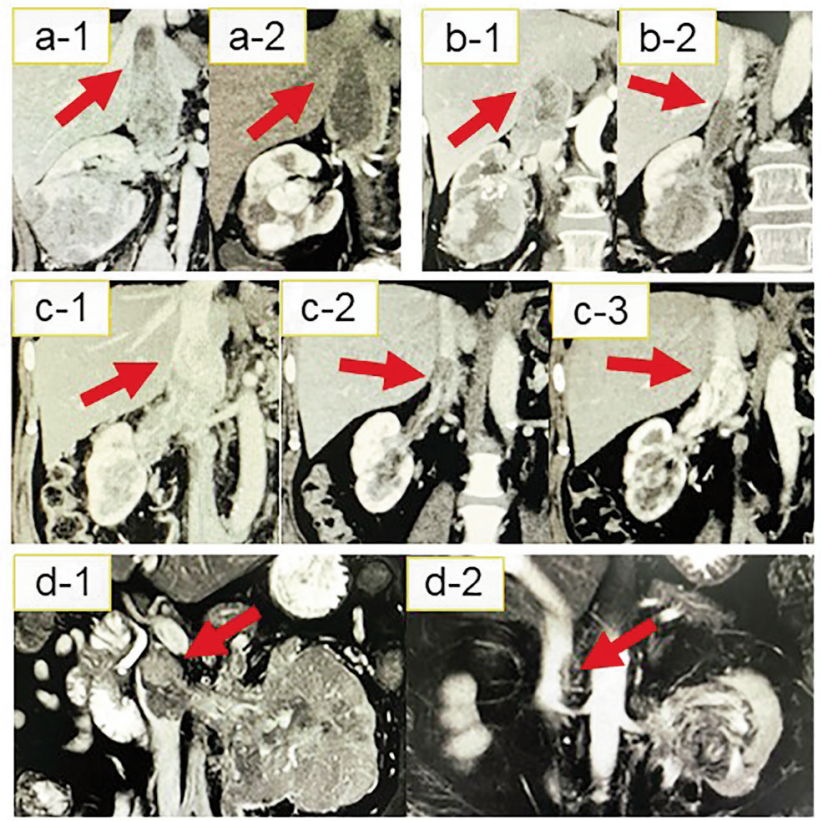

Figure 1. Inferior vena cava (IVC) tumour thrombi with changes (red arrows) revealed using computed tomography or magnetic resonance imaging in patients with renal cell carcinoma. (a-1, b-1, c-1, and d-1) Evaluation of IV tumour thrombi before combination treatment with immune checkpoint inhibitors (ICIs) in cases 1,2, 3, and 4, respectively. $(a-2, b-2, c-2$, and $d-2)$ The best responses of IVC tumour thrombi treated with ICIs was observed in cases 1, 2, 3, and 4, respectively. (c3) Case 3: An increase in the pre-existing IVC tumour thrombi one month after ICI therapy interruption owing to an immune-related adverse event. 
Table II. Clinical outcomes of combination treatment with immune checkpoint inhibitors in patients with renal cell carcinoma and inferior vena cava tumour thrombi.

\begin{tabular}{|c|c|c|c|c|c|c|c|c|c|}
\hline No. & $\begin{array}{c}\text { IVC } \\
\text { thrombus } \\
\text { level }\end{array}$ & $\begin{array}{l}\text { IVC } \\
\text { thrombus } \\
\text { distance } \\
\text { above the } \\
\text { renal vein, } \\
\text { mm (\%) }\end{array}$ & $\begin{array}{l}\text { Primitive } \\
\text { tumour, } \\
\text { mm }(\%)\end{array}$ & $\begin{array}{l}\text { Time from } \\
\text { the initiation } \\
\text { of ICIs to } \\
\text { surgery } \\
\text { (months) }\end{array}$ & $\begin{array}{l}\text { Surgery } \\
\text { after ICI } \\
\text { therapy }\end{array}$ & Metastases & $\begin{array}{l}\text { Overall } \\
\text { tumour } \\
\text { response }\end{array}$ & $\begin{array}{l}\text { Follow up } \\
\text { period from } \\
\text { the initiation } \\
\text { of ICIs } \\
\text { (months) }\end{array}$ & $\begin{array}{l}\text { Current } \\
\text { treatment }\end{array}$ \\
\hline 1 & $\begin{array}{l}\text { Level } \\
\text { IV } \rightarrow \text { III }\end{array}$ & $-44(-34)$ & $-37(-36)$ & 11 & $\begin{array}{l}\mathrm{RN} \text { and IVC } \\
\text { thrombectomy }\end{array}$ & $\begin{array}{c}\text { Lung } \\
\text { metastases } \\
\text { disappeared }\end{array}$ & $\begin{array}{l}\text { New brain } \\
\text { metastases } \\
\text { after surgery }\end{array}$ & 20 & $\begin{array}{l}\text { Ongoing } \\
\text { treatment }\end{array}$ \\
\hline 2 & $\begin{array}{l}\text { Level } \\
\mathrm{II} \rightarrow \mathrm{I}\end{array}$ & $-39(-48)$ & $-19(-26)$ & 4 & $\begin{array}{l}\text { RN and IVC } \\
\text { thrombectomy }\end{array}$ & $\begin{array}{c}\text { Lung } \\
\text { metastases } \\
\text { disappeared }\end{array}$ & No metastases & 13 & Interruption \\
\hline 3 & $\begin{array}{l}\text { Level } \\
\mathrm{II} \rightarrow \mathrm{II}\end{array}$ & $-19(-25)$ & $-17(-35)$ & 3 & $\begin{array}{l}\text { RN and IVC } \\
\text { thrombectomy }\end{array}$ & None & No metastases & 12 & Interruption \\
\hline 4 & $\begin{array}{l}\text { Level } \\
\mathrm{II} \rightarrow \mathrm{I}\end{array}$ & $-20(-36)$ & $-40(-36)$ & - & - & $\begin{array}{l}\text { Lung/lymph } \\
\text { node metastases } \\
\text { disappeared }\end{array}$ & Partial response & 8 & $\begin{array}{l}\text { Ongoing } \\
\text { treatment }\end{array}$ \\
\hline 5 & $\begin{array}{l}\text { Level } \\
\mathrm{II} \rightarrow \mathrm{II}\end{array}$ & $-37(-55)$ & $-56(-48)$ & - & - & $\begin{array}{l}\text { Lung metastases } \\
\text { shrank }\end{array}$ & $\begin{array}{l}\text { Progressive } \\
\text { disease }\end{array}$ & 18 & $\begin{array}{l}\text { Ongoing } \\
\text { treatment }\end{array}$ \\
\hline
\end{tabular}

ICI: Immune checkpoint inhibitor; IVC: inferior vena cava; RN: radical nephrectomy.

metastases, two of which also had lymph node metastases, and one had an additional metastatic lesion in the brain. According to the IMDC classification, the risk was intermediate in one and poor in four patients. Three patients received nivolumab plus ipilimumab and two received pembrolizumab plus axitinib therapy. The average ICI therapy duration was 10.0 months (range $=1-20$ months).

ICI therapy shrank the primary tumours, metastatic lesions, and IVC thrombi in all cases. The cases of IVC tumour thrombi are shown in Figure 1A-D. Treatment outcomes are summarized in Table II. In three of four patients with metastases, all metastatic lesions almost disappeared after treatment. The best responses recorded were: i) reductions in the diameter and height of the IVC tumour thrombus of $17 \mathrm{~mm}(43.6 \%)$ and $33 \mathrm{~mm} \mathrm{(39.0 \% ),}$ respectively, and ii) a reduction of $34 \mathrm{~mm}(36.1 \%)$ in the maximum diameter of the primary tumour lesion. The IVC thrombus level was eventually downstaged from IV to III in one patient and from II to I in another, while it did not increase during ICI therapy in any patient.

Following ICI therapy, RN with thrombectomy was performed in three patients, and a less invasive procedure could be employed in all of them. Notably, in case 1, the IVC intrathoracic level IV thrombus was downstaged to intrahepatic level III, thus, extensive thoracotomy was not required. Instead, this patient underwent a surgical procedure using a less invasive vascular approach for clamping the supra hepatic IVC, which included extensive hepatic mobilization and infrarenal IVC, along with contralateral renal vein control. Cases 2 and 3 , whose intrahepatic IVC
IVC tumour thrombus

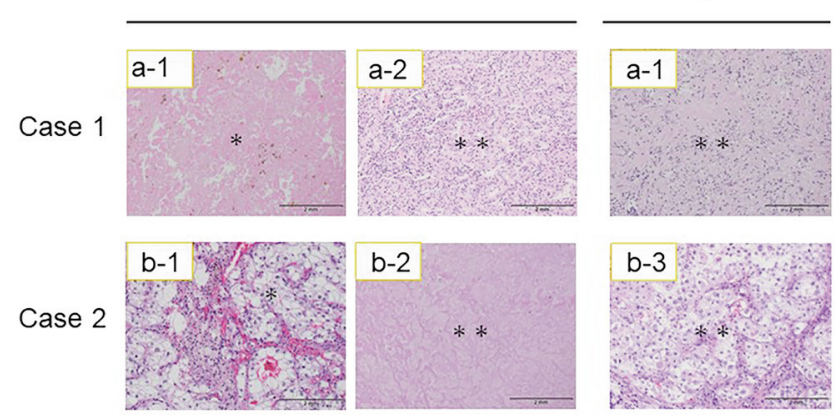

Figure 2. Microscopic appearance of inferior vena cava (IVC) tumour thrombi and primary tumours after combination treatment with immune checkpoint inhibitors. The two haematoxylin and eosin-stained sections on the left were taken from IVC tumour thrombi and those on the right are from primary tumours. Residual malignant cells are present (double asterisk) in these tumours, as was the necrotic tissue that replaced the IVC tumour thrombus (asterisk). Scale bar $=2 \mathrm{~mm}$.

tumour thrombi decreased to level II, did not require extensive hepatic mobilization and underwent intra hepatic IVC clamping on the atrial side; the remaining procedure was the same as above. In these patients, the average total operation time was 329 minutes and blood loss was 1,479 $\mathrm{ml}$. No patient developed perioperative complications. The average postoperative hospitalization period was seven days. Clear-cell RCC was diagnosed based on percutaneous biopsy or RN with thrombectomy findings in all five patients. Much of the resected primary tumours and IVC tumour thrombi 
showed ICI therapy-induced tissue necrosis. Despite this, viable tumour cells, albeit slightly degenerated, persisted in all cases (Figure 2). Three patients experienced major adverse effects (AEs) of grades higher than CTCAE grade 2. Two of these patients received high-dose steroid therapy. One patient discontinued ICI therapy due to grade IV liver dysfunction. This patient was preoperatively suspected of tumour invasion to the IVC wall; thus, we decided to use ICIs during the preoperative waiting period. The tumour thrombus level in this patient increased again one month after treatment interruption. The patient (case 3) underwent RN and IVC thrombectomy with part of the IVC wall resected immediately after this immune-related AE (irAE) was managed. Three patients showed no sign of local recurrence or distant metastases nine months after surgery on average; however, one needed radiation therapy for brain metastasis after surgery.

\section{Discussion}

In the present study, we report our experience with ICI therapy in five RCC patients with IVC tumour thrombi. The height and width of IVC thrombi rapidly was reduced by approximately $39.0 \%$ and $43.6 \%$, respectively, in $1-3$ months. The maximum primary tumour diameter rapidly decreased by approximately $36.1 \%$, whereas the IVC tumour thrombus was downstaged in two patients $(40 \%)$. These results suggest that ICI therapy may effectively reduce tumour thrombi, leading to presurgical treatment in some patients. Interestingly, distant metastases disappeared after ICI therapy in settings where surgery was considered unsafe or unfeasible. Furthermore, shrinking tumour thrombi inside the IVC and renal veins through presurgical treatment may facilitate the control of bleeding during surgery as venous return stasis is improved $(4,16)$. Three of our five patients who underwent RN and thrombectomy may have benefited in terms of surgical strategy modification or risk reduction.

There is a risk of delay in radical nephrectomy due to the occurrence of AEs or irAEs. In two long-term randomized trials for patients with advanced renal carcinomas without thrombi, namely the Checkmate 214 trial (ipilimumab+nivolumab) and the KEYNOTE-426 trial (pembrolizumab+axitinib), treatment-related AEs leading to treatment discontinuation occurred in $22.7 \%$ and $10.1 \%$ of the patients, respectively $(11,12)$. These trials showed that the progressive disease risk was $20 \%$ and $10.9 \%$ in the respective groups. It could, therefore, be of importance to consider the possibility of upfront surgery without presurgical ICI therapy as a more suitable strategy for patients with IVC tumour thrombi.

In our study, the patient who discontinued their treatment due to irAEs presented with tumour growth and progression one month after treatment discontinuation.
Eventually, the shrinkage of the IVC tumour thrombi allowed the patient to undergo a minimally invasive surgery, as described above. This case suggested that even if ICI treatment has a remarkable effect on shrinking IVC tumour thrombi, its effect would likely disappear upon discontinuation of the treatment. In patients who underwent surgery, some viable cells of the primary tumour and IVC tumour thrombus lesions persisted even after ICI therapy.

Our data are biased because of their retrospective acquisition, the short observation period, and the small number of cases. The perioperative management of RCC with IVC tumour thrombi remains to be established. This study suggests that presurgical ICI therapy may be advisable for a select cohort of RCC patients with IVC thrombi. However, ICIs can cause serious irAEs, as in the present study, or even disease progression $(11,12)$, and their application should be carefully thought out. It is necessary to always consider pulmonary embolism or progressive disease risk due to IVC tumour thrombi and carefully monitor it until surgery.

In conclusion, ICI therapies for RCC patients with IVC tumour thrombi appear to result in primary tumour shrinkage and thrombus reduction. Surgery may be the first choice for these patients; however, our results suggest that presurgical ICI therapies offer benefits, such as reducing the need for invasive surgical procedures in select patients.

\section{Conflicts of Interest}

All Authors have no conflicts of interest to declare.

\section{Authors' Contributions}

$\mathrm{KY}$ wrote this manuscript and provided a table and figure. $\mathrm{KH}$, JI, TK, HI, HI, KT, and TT cared for the patients, administered the combination therapy, and performed surgery. Pathological findings were evaluated by YN. All Authors contributed to the conception and design of this study as well as to the acquisition, analysis, and interpretation of data. All Authors read and approved the final manuscript.

\section{References}

1 Lambert EH, Pierorazio PM, Shabsigh A, Olsson CA, Benson MC and McKiernan JM: Prognostic risk stratification and clinical outcomes in patients undergoing surgical treatment for renal cell carcinoma with vascular tumor thrombus. Urology 69(6): 1054-1058, 2007. PMID: 17572185. DOI: 10.1016/ j.urology.2007.02.052

2 Abbasi A, Johnson TV, Ying K, Baumgarten D, Millner R and Master VA: Duplicated vena cava with tumor thrombus from renal cancer: use of venogram for safer operative planning. Urology 79(4): e57-e58, 2012. PMID: 21862114. DOI: 10.1016/ j.urology.2011.06.044

3 Bedke J, Albiges L, Capitanio U, Giles RH, Hora M, Lam TB, Ljungberg B, Marconi L, Klatte T, Volpe A, Abu-Ghanem Y, 
Dabestani S, Fernández-Pello S, Hofmann F, Kuusk T, Tahbaz R, Powles T and Bex A: Updated European Association of Urology guidelines on renal cell carcinoma: Nivolumab plus cabozantinib joins immune checkpoint inhibition combination therapies for treatment-naïve metastatic clear-cell renal cell carcinoma. Eur Urol 79(3): 339-342, 2021. PMID: 33357997. DOI: $10.1016 /$ j.eururo.2020.12.005

4 Klatte T, Pantuck AJ, Riggs SB, Kleid MD, Shuch B, Zomorodian N, Kabbinavar FF and Belldegrun AS: Prognostic factors for renal cell carcinoma with tumor thrombus extension. J Urol 178(4 Pt 1): 1189-95; discussion 1195, 2007. PMID: 17698087. DOI: 10.1016/j.juro.2007.05.134

5 Horn T, Thalgott MK, Maurer T, Hauner K, Schulz S, Fingerle A, Retz M, Gschwend JE and Kübler HR: Presurgical treatment with sunitinib for renal cell carcinoma with a level III/IV vena cava tumour thrombus. Anticancer Res 32(5): 1729-1735, 2012. PMID: 22593453.

6 Vicente E, Quijano Y, Ielpo B, Duran H, Diaz E, Fabra I, Malavé L, Ferri V, Ferronetti A and Caruso R: Surgical resection of malignancies invading inferior Vena Cava level I and II. Issues still need to be discussed. Anticancer Res 37(5): 2523-2528, 2017. PMID: 28476822. DOI: 10.21873/anticanres.11594

7 Cost NG, Delacroix SE Jr, Sleeper JP, Smith PJ, Youssef RF, Chapin BF, Karam JA, Culp S, Abel EJ, Brugarolas J, Raj GV, Sagalowsky AI, Wood CG and Margulis V: The impact of targeted molecular therapies on the level of renal cell carcinoma vena caval tumor thrombus. Eur Urol 59(6): 912-918, 2011 PMID: 21367518. DOI: 10.1016/j.eururo.2011.02.032

8 Bigot P, Fardoun T, Bernhard JC, Xylinas E, Berger J, Rouprêt M, Beauval JB, Lagabrielle S, Lebdai S, Ammi M, Baumert H, Escudier B, Grenier N, Hétet JF, Long JA, Paparel P, RiouxLeclercq N, Soulié M, Azzouzi AR, Bensalah K and Patard JJ: Neoadjuvant targeted molecular therapies in patients undergoing nephrectomy and inferior vena cava thrombectomy: is it useful? World J Urol 32(1): 109-114, 2014. PMID: 23624719. DOI: 10.1007/s00345-013-1088-1

9 Ujike T, Uemura M, Kawashima A, Nagahara A, Fujita K, Miyagawa $\mathrm{Y}$ and Nonomura N: Clinical and histopathological effects of presurgical treatment with sunitinib for renal cell carcinoma with inferior vena cava tumor thrombus at a single institution. Anticancer Drugs 27(10): 1038-1043, 2016. PMID: 27557138. DOI: $10.1097 / C A D .0000000000000422$

10 Fukuda H, Kondo T, Takagi T, Iizuka J, Nagashima Y and Tanabe K: Limited benefit of targeted molecular therapy for inferior vena cava thrombus associated with renal cell carcinoma. Int J Clin Oncol 22(4): 767-773, 2017. PMID: 28365808. DOI: 10.1007/s10147-017-1119-9
11 Motzer RJ, Tannir NM, McDermott DF, Arén Frontera O, Melichar B, Choueiri TK, Plimack ER, Barthélémy P, Porta C, George S, Powles T, Donskov F, Neiman V, Kollmannsberger CK, Salman P, Gurney H, Hawkins R, Ravaud A, Grimm MO, Bracarda S, Barrios CH, Tomita Y, Castellano D, Rini BI, Chen AC, Mekan S, McHenry MB, Wind-Rotolo M, Doan J, Sharma P, Hammers HJ, Escudier B and CheckMate 214 Investigators: Nivolumab plus ipilimumab versus sunitinib in advanced renalcell carcinoma. N Engl J Med 378(14): 1277-1290, 2018. PMID: 29562145. DOI: 10.1056/NEJMoa1712126

12 Rini BI, Plimack ER, Stus V, Gafanov R, Hawkins R, Nosov D, Pouliot F, Alekseev B, Soulières D, Melichar B, Vynnychenko I, Kryzhanivska A, Bondarenko I, Azevedo SJ, Borchiellini D, Szczylik C, Markus M, McDermott RS, Bedke J, Tartas S, Chang YH, Tamada S, Shou Q, Perini RF, Chen M, Atkins MB, Powles T and KEYNOTE-426 Investigators: Pembrolizumab plus axitinib versus sunitinib for advanced renal-cell carcinoma. N Engl J Med 380(12): 1116-1127, 2019. PMID: 30779529. DOI: $10.1056 /$ NEJMoa1816714

13 Sobin LH and Compton CC: TNM seventh edition: what's new, what's changed: communication from the International Union Against Cancer and the American Joint Committee on Cancer. Cancer 116(22): 5336-5339, 2010. PMID: 20665503. DOI: $10.1002 /$ cncr. 25537

14 Heng DY, Xie W, Regan MM, Warren MA, Golshayan AR, Sahi C, Eigl BJ, Ruether JD, Cheng T, North S, Venner P, Knox JJ, Chi KN, Kollmannsberger C, McDermott DF, Oh WK, Atkins MB, Bukowski RM, Rini BI and Choueiri TK: Prognostic factors for overall survival in patients with metastatic renal cell carcinoma treated with vascular endothelial growth factortargeted agents: results from a large, multicenter study. J Clin Oncol 27(34): 5794-5799, 2009. PMID: 19826129. DOI: 10.1200/JCO.2008.21.4809

15 Neves RJ and Zincke H: Surgical treatment of renal cancer with vena cava extension. Br J Urol 59(5): 390-395, 1987. PMID: 3594097. DOI: 10.1111/j.1464-410x.1987.tb04832.x

16 Okamura Y, Terakawa T, Sakamoto M, Bando Y, Suzuki K, Hara T, Furukawa J, Harada K, Hinata N, Nakano Y and Fujisawa M: Presurgical pazopanib improves surgical outcomes for renal cell carcinoma with high-level IVC tumor thrombosis. In Vivo 33(6): 2013-2019, 2019. PMID: 31662532. DOI: 10.21873/invivo. 11698

Received October 26, 2021

Revised December 3, 2021

Accepted December 15, 2021 